\title{
Using a Learning Management System to Foster Independent Learning in an Outcome-Based University: A Gulf Perspective
}

\author{
Azzedine Lansari and \\ Abdallah Tubaishat \\ Zayed University, Abu Dhabi, UAE \\ azzedine.lansari@zu.ac.ae; \\ abdallah.tubaishat@zu.ac.ae
}

\author{
Akram Al-Rawi \\ DeVry University Online, \\ Columbia, MO, USA
}

\begin{abstract}
A survey based study was initiated in an outcome-based academic institution located in the Gulf region. The goal of this study was to learn about the students' attitude toward using a learning management system (LMS) (Blackboard learn ${ }^{+}$) to take charge of their learning and to assess the awareness of the students about the learning outcomes used in the university IT programs. The survey was developed to target students in the College of Information Technology and included three categories: Learning Outcomes, Effective Use of Technology, and Communication and Confidence Development. In the first category, questions were asked to learn about the students' understanding of how learning outcomes are used in the IT College and University. In the second category, questions were asked to learn about the students' ability and willingness to use Blackboard in their courses. In the third category, questions were asked to learn about the students' preferred mode of communication and whether using Blackboard helped them build confidence and become independent learners.

Study results showed that the majority of students are aware that the College uses specific learning outcomes in all courses and which learning outcomes are included in course syllabi. Moreover, students indicated a willingness to use Blackboard on a daily basis to check for course materials, grade updates and take online assessments. Most students felt like they became more confident in expressing their opinions and ideas using communication technologies. Students also indicated that using online learning has improved their technical skills and the resources posted on the LMS allowed them to learn more about related course topics. The students' preferred mode of communication was email rather than face to face meetings. Their least favorite mode of communication was the LMS discussion board. Students felt like they became more confident in expressing their opinions and ideas using communication technologies and that using online learn-

Material published as part of this publication, either on-line or in print, is copyrighted by the Informing Science Institute. Permission to make digital or paper copy of part or all of these works for personal or classroom use is granted without fee provided that the copies are not made or distributed for profit or commercial advantage AND that copies 1) bear this notice in full and 2) give the full citation on the first page. It is permissible to abstract these works so long as credit is given. To copy in all other cases or to republish or to post on a server or to redistribute to lists requires specific permission and payment of a fee. Contact Publisher@,InformingScience.org to request redistribution permission.

ing helped improved their technical

skills. Finally, students felt that while web resources allowed them to become independent learners, they still needed the guidance of instructors.

The knowledge gained from this research could contribute to understanding the online modality of higher education in this region. Universities in this region are struggling to find solutions to the students' dependence on teachers. Using
\end{abstract}


a technology mediated learning environment can provide a solution to improve academic performance, students confidence and help students become independent learners. Moreover, instructors can help by choosing the most appropriate teaching methods to foster student learning in segregated academic institutions.

Keywords: Outcome-based education, Learning management tools, E-learning.

\section{Introduction}

Information and communication technology (ICT) has become a popular tool to facilitate and enhance teaching and learning. Many academic institutions are using ICT to provide support to their curriculum, expand student learning experiences and support the institution's academic program learning outcomes. Moreover, a number of universities are using ICT to be more competitive (Norman, 2007). The Gulf region has seen a major increase in the presence of universities from North America, Europe and Australia. Most of them offer a combination of face to face and distance learning programs. The number of students enrolling in these universities has increase dramatically as people are increasingly moving to the Gulf region for employment (Al-Doub, Goodwin, \& Al-Hunaiyyan, 2008; Biju, 2010).

Students in the Gulf face difficulties when joining universities offering US and Western style academic programs. One major challenge is the learning habits and styles that students have acquired while in middle and high school. Students are used to the guided teaching and fact based model compared to the independent project based model used in higher academic institutions particularly those offering distance learning programs. The second challenge comes from the fact that students in this part of the world generally graduate from segregated primary and secondary schools that focus on memorization to gain knowledge. Therefore, students have learned to completely depend on their teachers for acquiring knowledge. As a result the concept of problem solving and critical thinking is almost foreign to the majority of the students. This problem seems to be more severe with female students joining higher education institutions. Statistics show that more than two third of the students joining Colleges and Universities in the region are female students. Most public universities in this region are segregated and are trying to find solutions to the dependence of students on teachers. Some academic institutions have identified solutions that include using technology in the classrooms; others have adopted alternative educational models to encourage students to become independent learners and requiring them to own a laptop for an alternative way to learn, communicate, access resources, and share information.

A recently established outcome-based university, Zayed University (ZU) has campuses for both female and male students. ZU offers specializations in the fields of business, communication and media sciences, education, information technology and arts and sciences. This segregated university uses an American educational model and has recently achieved accreditation by the Middle States Accreditation Body (http://www.msche.org/). Since its establishment, the University has focused on having a high tech campus that provides the latest technology to facilitate learning. The campus provides students and faculty with wired and wireless connections to various electronic resources. Currently, the University requires every student to purchase a laptop computer. In the year 2000, the University adopted an outcome based Academic Program Model (APM) to provide focus to its curricula and measure student achievement. Two sets of learning outcomes were adopted by the University. University learning outcomes (ULO) are high-level outcomes that focus on life skills, and College specific learning outcomes (CLO) which relate to the abilities needed by students to be successful in their field of study upon graduation.

The University provides a technology mediated learning environment where each student and instructor has access to a wide range of ICT tools to communicate, collaborate and share resources. These tools provide anytime anywhere learning opportunities. Currently, more than 
5,000 students have access to courses and learning materials on campus and from home via the Blackboard Course Management System (http://www.blackboard.com ). The University requires that all instructors use BB for their course delivery and management. The instructor's uses of BB vary widely from only posting grades and course information to online delivery, assessment and feedback, discussion and communication. At the beginning of the semester, each instructor has to post on BB an electronic version of the course syllabus that must include the learning outcomes addressed in that particular course. Moreover, students use BB to post various pieces of evidence to show achievement of specific learning outcomes. Finally, the instructors assess student work and post her/his feedback on BB.

Some researchers argue that e-learning education provides more effective learning experiences to students and leads to better academic performance (Altenhofen, \& Schaper, 2002; Gagne, Wager, Golas, Keller, \& Russell, 2005; Hodges, 2004). Motivation is one of the most critical components of learning in an educational environment. Motivation has been defined by Maslow (1970) as a psychological process where a behavior is directed toward a goal based on individual needs. Gagne et al. (2005) argue that learner motivation can be affected by external aspects, such as positive engagement by tutors and peers. Lee (2000) reported the importance of motivation on learners' performance, particularly in a technology-mediated environment. Even though the importance of learners' motivation, their interaction and the benefits of blended learning have been reported in the literature (Kinshuk \& Young, 2003; Muhlauser \& Trompler, 2002; Norman, 2007), little is known about what motivates and discourages online learners in the Gulf region. This results in a number of fundamental questions about the types of interaction that take place among faculty and learners, the influences on this interaction, and the barriers that learners face while interacting online with their peers and instructors (Neubauer \& Lobel, 2003; Smith \& Winking-Diaz, 2004; Vekroost, Meijerink, Linsten, \& Veen, 2008).

\section{Learning Environment at Zayed University}

From its establishment in 1998, ZU has had the opportunity to choose and build upon the best available academic models in higher education. The University was established to provide higher education to local female students and has recently begun admitting male students in a separate campus. University policy requires students to be on-campus during the normal operating hours (7 AM to $5 \mathrm{PM}$ ). An electronic check-in and check-out system is used to ensure that students remain on-campus once they are in the facilities. Female students are not allowed to leave campus without their families' permission. Attendance is taken during each teaching session to ensure that students are present and participate in class activities. During off-campus educational activities, female students must be accompanied by both female faculty and staff.

$\mathrm{ZU}$ provides a strong commitment to the APM which was developed by faculty to emphasize learning as opposed to the traditional lecturing style. This is a shift in the teaching paradigm were the focus is on student learning and where College and University learning outcomes are used to improve both curricula as well as teaching and learning practices. Therefore, the APM focuses more on what students can actually do after they graduate rather than what they retain from their courses. Details about this academic model can be found in the Zayed University web site (http://www.zu.ac.ae).

\section{The Outcome Based Academic Program Model (APM)}

The purpose of the outcome based model is to provide students a focused and coherent academic program and to prepare our graduate students for a rapidly changing and unpredictable future. It is outcome driven and uses the traditional Grade Point Average (GPA) system. The framework that constitutes the academic model is composed of three components: 
- Readiness program to ensure that students are competent in English language

- General Education

- Degree Majors

A major objective of the undergraduate experience at $\mathrm{ZU}$ is the development of the skills necessary for continuous lifelong learning. The APM is designed to help achieve this objective by providing students with a foundation and framework for all university studies. Every ZU course focuses on one or more of the six university-specified learning outcomes. The learning outcomes are incorporated into normal course work, and therefore are an integral part of disciplinary content and evaluation of the course. Threaded throughout the baccalaureate curriculum, the learning outcomes help students achieve a higher order of intellectual development. ZU has the following graduation requirements for all students regardless of their major:

- Information Literacy and Communication: ZU graduates will be able to recognize information needs, access and evaluate appropriate information to answer those needs, and communicate effectively to a variety of audiences in both English and Arabic.

- Information Technology: ZU graduates will be critically aware of the implications of information technology on the individual and on society, and be able to use IT to communicate and solve problems in an ethical way.

- Critical Thinking and Quantitative Reasoning: ZU graduates will be able to use information, reasoning, and creative processes to achieve goals and make responsible decisions.

- Global Awareness: ZU graduates will be able to relate to communities beyond the local, perceive and react to differences from an informal and reasoned point of view, and be critically aware of the implications and benefits of cultural interaction.

- Teamwork and leadership: ZU graduates will be able to work efficiently and effectively in a group. ZU graduates will be able to assume leadership roles and responsibilities in a variety of life situations and accept accountability for the results.

- Bilingual: ZU graduates will be able to communicate effectively (oral and in writing) in both English and Arabic.

The College of Information Technology (CIT) has established five learning outcomes that complement the learning outcomes of the ZU APM. These major learning outcomes form the basis for analysis and assessment that play an essential role in the continuous process of improvement. The major learning outcomes of the CIT College are as follows:

- Problem Identification and Analysis: CIT graduates will be able to organize, define, and classify problems.

- Problem Solving: CIT graduates will derive solutions and evaluate their success.

- Information Technology and their Application and Managements: CIT graduates will understand the capabilities, use, and application of information technologies.

- Systems Principles and Practices: CIT graduates will demonstrate understanding of system types, structure, standards, and metrics.

- Technical Communication: CIT graduates will organize, develop, present, and evaluate technical material. 


\section{Case Study Methodology}

A survey was developed and administered to female and male students to learn about their awareness and understanding of College and University learning outcomes (LOs) and how LOs are used in various courses (See Appendix A). Furthermore, the survey also tackles the issue of using technology to facilitate learning and communication. The students were asked to give their opinion on using technology-mediated learning environment and how it may motivate their learning. The survey was developed to be easily understood by the students as English is not their first language. It consisted of 20 questions grouped into six categories: learning outcomes, effective use of technology, preferred mode of communication, use of electronic mail, technical skill development, and confidence development.

Students from two different levels of their studies in the CIT were selected to participate in this study. The first cohort consisted of 35 female students taking two sophomore courses (Introduction to IT and Systems and Discrete Mathematics for Computing). The second cohort consisted of 22 female students taking two junior level courses (Database Systems and Dynamic Web Development). The third cohort consisted of 40 male students taking one freshman (IT Career Exploration) and one sophomore course (Introduction to IT and Systems). The small size of the University and the College resulted in a small number of participants in this study. Currently, around 5000 students are enrolled in both campuses.

The students surveyed in this study attend classical lectures where students meet the instructor in a face-to-faces setting. Additionally they use educational and communication technologies such as online resources, videoconferencing, electronic mail, IM applications, and discussion board to enrich their learning experiences and communicate with instructors and fellow students. Instructors, on the other hand, are required to use instructional technologies including BB to build a rich learning environment and to deliver and manage their courses. Specific tools used in this learning environment fall into the following four categories:

- Content management tools: they allow instructors to present course content online. Including announcements, course information, and course material and references related to the course topics.

- Communication and collaboration tools: they allow instructor-student, and studentstudent communication via discussion board, and email messaging.

- Assessment tools: they allow instructors to generate exams as well as other assessments such as case studies and assignments, and make them available to students. Instructors post students grades and students can view their grades using BB grade book.

\section{Survey Analysis and Results}

The survey analysis was done in steps as shown in Appendix B. First, questions were grouped to be in one of three categories: Learning Outcomes, Effective Use of Technology and Communication and Confidence Development. In the first category, five questions were used to learn about the students' understanding of how learning outcomes are used in the APM and in various courses in the IT College. In the second category, five questions were used to learn about the students' ability and willingness to use BB in their courses, including: course information retrieval, completing and submitting assessments and getting instructor feedback. In the third and last category, ten questions were used to learn about the students' ability and willingness to communicate with the instructor and other students using one of four modes of communication: email, face to face, telephone, and the BB discussion board. 


\section{Learning Outcomes}

In order to understand whether students in the IT College are aware about how learning outcomes are used in the College and University, the following five questions were asked in the survey (results are shown in Figure 1):

Q1: I am aware that ZU is an outcome based university.

Q2: I know what the Zayed University Learning Outcomes are.

Q3: I am aware that all IT courses include learning outcomes.

Q4: I am aware that learning outcomes are included in the course syllabus.

Q5: I know which learning outcomes are included in my IT courses.

The response to the first question: "I am aware that ZU is an Outcome-based University" was positive as 74 percent of female students responded with either strongly agree or agree. Almost all male students were aware that $\mathrm{ZU}$ is an outcome based university with a response of 98 percent. The response to the second question: "I know what the ZU Learning Outcomes are" was again positive as 71 percent of the female students responded with strongly agree or agree. The male students' response was close to the female response with a 68 percent responding that they know what ZU Learning outcomes are. The student awareness that all IT courses include learning outcomes was overwhelmingly evident as 81 percent of the female and 93 percent of the male students responded with agree or strongly agree to that question. Moreover, 77 percent of the female students and 90 percent of the male students are aware that all IT course syllabi include learning outcomes.

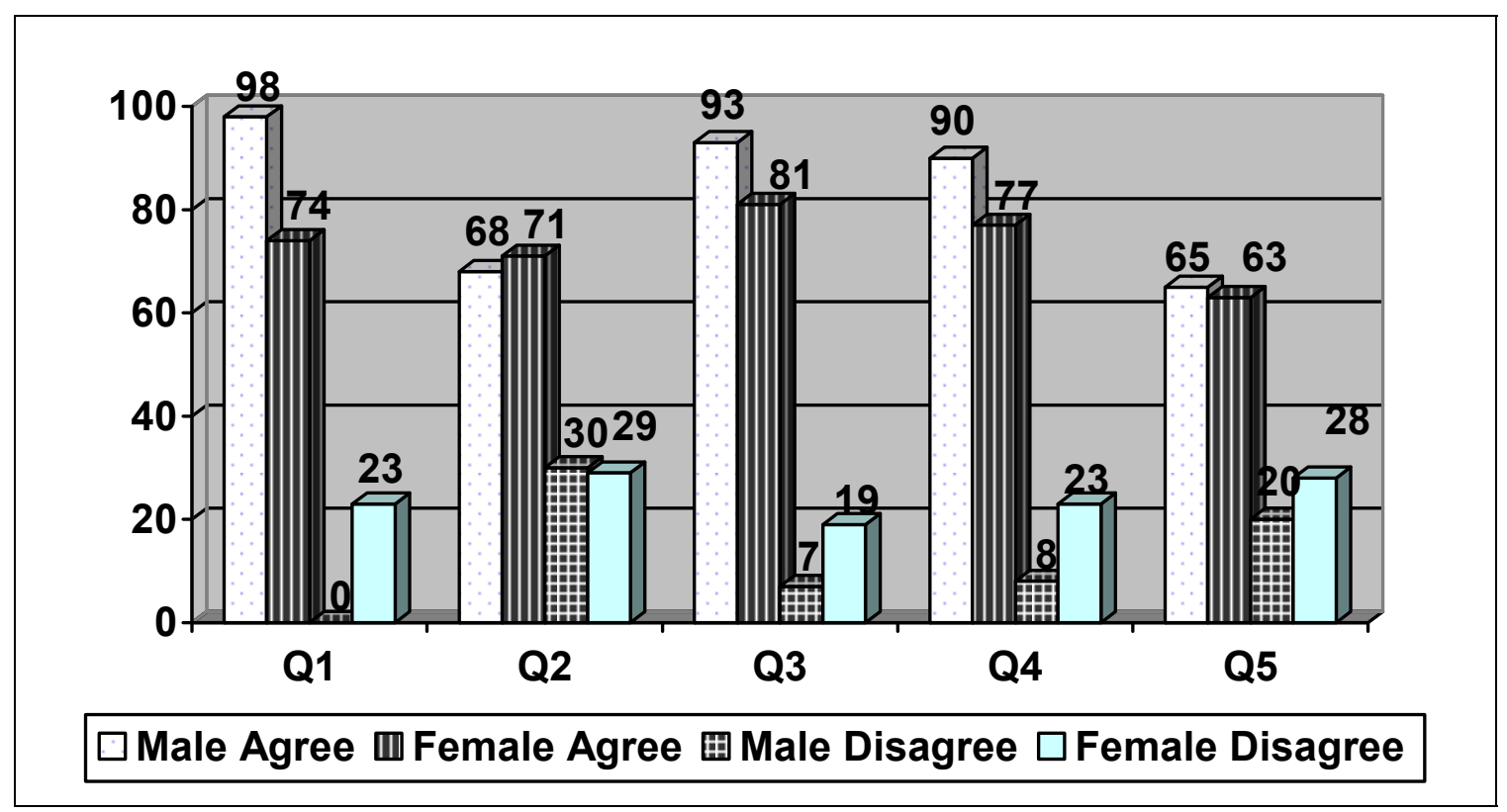

Figure 1: Female versus Male Perspective on Learning Outcomes

However, only 63 percent of all female students and 65 percent of all male students indicated that they knew which learning outcomes are included in the syllabi of the courses they were enrolled in. Overall, the male students in the IT College seem to be more aware and knowledgeable about the University use of learning outcomes. When it comes to their courses, both male and female seem to have the same knowledge about the leaning outcomes which are used in their courses. 


\section{Effective Use of Technology}

In order to understand the effective use of available technology to facilitate student learning and communication in the IT College, the following five questions were asked in the survey (results are shown in Figure 2):

Q1: I have no problem accessing Blackboard from home.

Q2: I check Blackboard at least once a day.

Q3: I regularly check my online grade book.

Q4: Online grade book keeps me informed about my progress.

Q5: I like the idea of having online exams, quizzes, class activities, etc.

The first question was about the ability to remotely access BB from areas outside the campus. While 91 percent of female students responded as having no problems accessing BB remotely only 73 percent of male students responded as having no problems. The second question was about how often students access BB during a particular day. Only 70 percent of female students indicated that they accessed BB at least once a day and 83 percent of male students indicated that they access BB more than once a day.

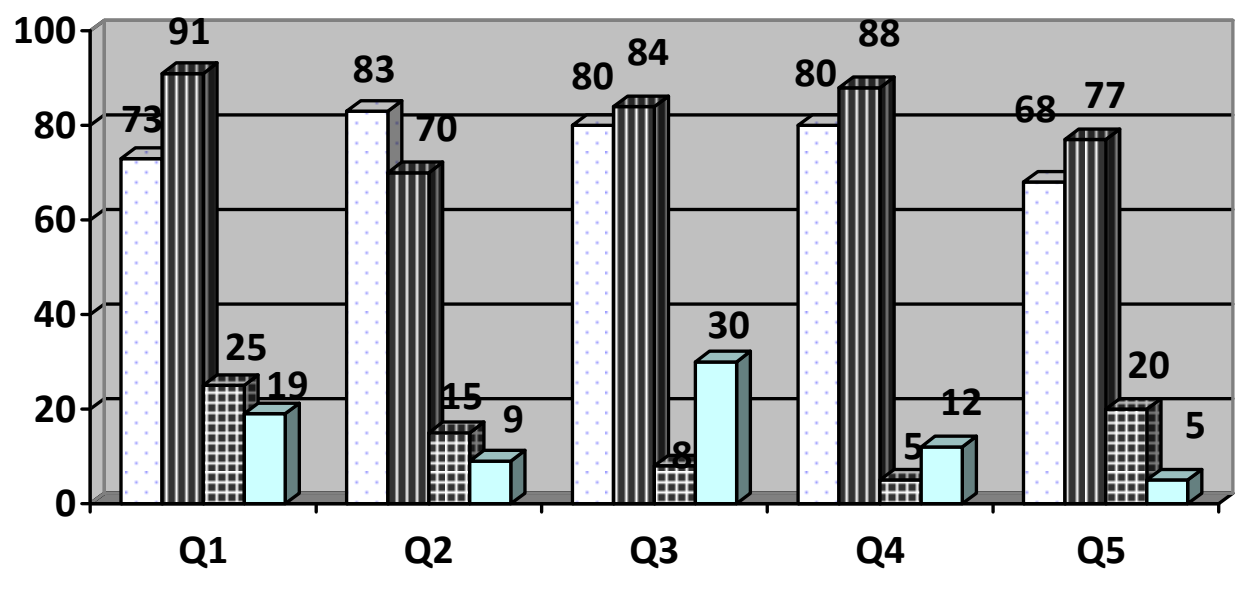

\section{$\square$ Male Agree $\amalg$ Female Agree $\mathbb{\#}$ Male Disagree $\square$ Female Disagree}

Figure 2: Female versus Male Perspective on Technology Use to Facilitate Learning

The following three questions were about assessments and feedback. A fairly high percentage of both male and female students indicated that they regularly check their grades online. Specifically, 84 percent of females and 80 percent of males responded as either agree or strongly agree. Moreover, 88 percent of female students and 80 percent of male students indicated that they check BB Grade book regularly to keep informed of their academic progress. Finally, 77 percent of female students indicated that they liked the idea of taking online exams and/or assessments, but only 68 percent of male students indicated that they liked the idea.

\section{Communication and Confidence Development}

ZU has evolved from an all female university to a university that accepts male student that are located in a separate campus. Male faculty is allowed to teach on either campus. Due to local customs, some female students prefer not to interact with male faculty directly and may be more comfortable using other modes of communication. Therefore, a major component of this survey 
consisted of questions to learn about the students preferred mode of communication and whether BB can help them build their confidence and allow them to become independent learners.

\section{Preferred Mode of Communication}

The first question in this section of the survey was about what is the student's preferred mode of communication. Four choices were offered: Using email, face to face communication, using the telephone, and using the BB Discussion board. Results for the female students show that 42 percent of them reported that their preferred mode of communication is email, followed by 40 percent preferring face to face meetings with their instructors, 14 percent prefer using the telephone, and only 5 percent prefer using the BB discussion board. Results for the male students show that 33 percent prefer using email, 43 like to use face to face meetings, 5 percent prefer using the telephone and only 3 percent like using the BB discussion board.

\section{Use of Electronic Mail}

In order to learn more about why students prefer using email to communicate with each other or with their instructors and also if by using email they developed the ability to communicate clearly, three questions were asked in the survey (results are shown in Figure 3):

Q1: I use email to communicate with fellow students.

Q2: I use email to communicate with my instructor in this class.

Q3: I have developed the ability to communicate clearly.

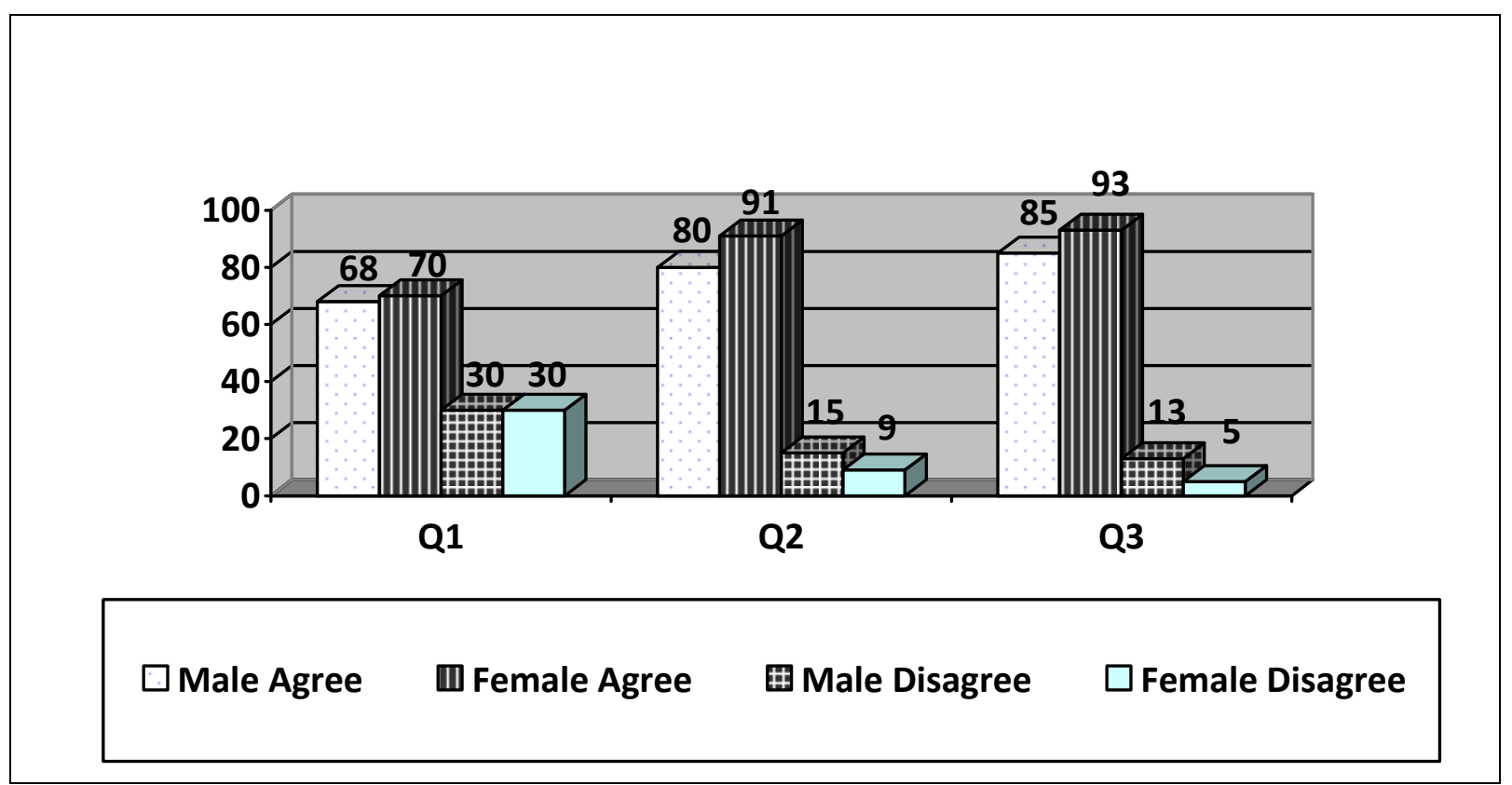

Figure 3: Female versus Male Perspective on the Use of Technology for Communication

The first question was about the students' choice to use email to communicate with other students. A similar response was received by both female and male students (respectively 70 percent and 68 percent). The next question was about the students' choice to use email to communicate with their instructors. In this case, more females than males responded that they like using email. Specifically, 91 percent of female students and 80 percent of male students replied that they use email to communicate with their instructors. Similarly, 93 percent of female students indicated that they developed the ability to communicate clearly because of email. The male students' response was lower with at 85 percent for this question. 


\section{Technical Skill Development}

In order to learn about whether students technical skills have improved using online resources, such as posted course material, online resources, availability of electronic library resources, two questions were asked in the survey (results are shown in Figure 4):

Q1: Using online learning has improved my technical skills.

Q2: The web resources listed on the course's webpage allow me to learn more about my courses.

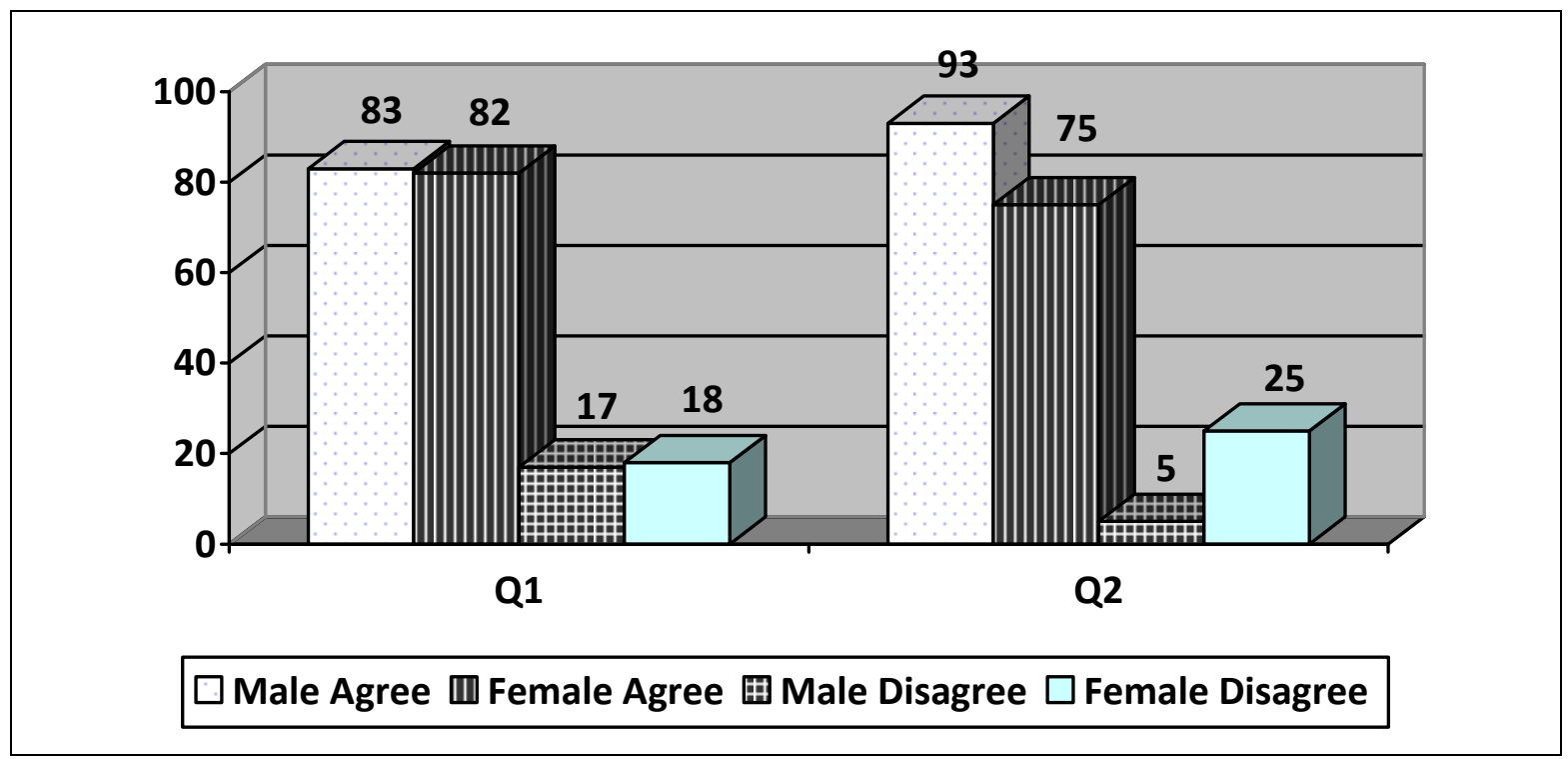

Figure 4: Female versus Male Perspective on Technical Skill Development

The first question was about if online learning has improved the students' technical skills, eighty thee percent of male students and 82 percent of female students responded with agree and strongly agree. Moreover, 18 percent of both female and male students seem to either disagree or strongly disagree. One possible reason for the similar responses could be that both male and female students have access to exactly the same resources and most students like using the provided online resources to supplement the courses. The second question was about whether the additional resources provided to the students on BB helped them improve their learning abilities. 93 percent of male students responded as either agree or strongly agree and 75 percent of male students responded similarly. Interestingly, 25 percent of female students either disagree or strongly disagree versus only five percent of male students. This big gap may be explained by the fact that male students in this culture are more independent and sometimes more confident than female students and therefore don't rely on the instructors as much. Therefore, looking at the students' responses it seems that more male students think that they learn more from the provided additional online resources than their female counterpart.

\section{Confidence Development}

In order to learn about the impact of online resources on the students confidence in taking charge of their learning and whether using a learning management system such as BB improved the students' ability to become independent learners, four questions were asked in this survey (results are shown in Figure 5): 
Q1: Using online learning allows me to be more independent.

Q2: I feel more comfortable posting my opinions on the discussion board rather than to speak up in class.

Q3: Using Online Learning make me less dependent on my teachers for help.

Q4: I become more confident in expressing my ideas using communication technologies such as email, chat, and discussion forum.

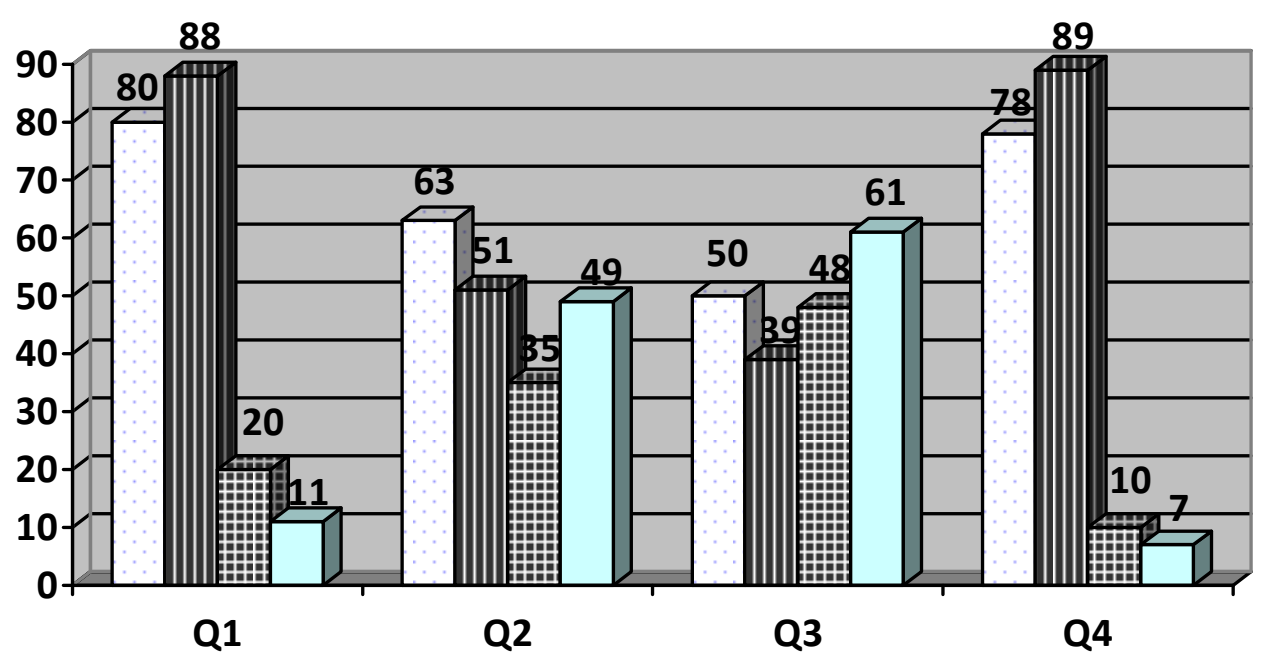

Male Agree $\square$ Female Agree $\boxplus$ Male Disagree $\square$ Female Disagree

Figure 5: Female versus Male Perspective on Confidence Development

The first question was about the impact of online learning on the students' ability to become independent, 88 percent of female students responded with agree or strongly agree versus 80 percent of male students. Only, 11 percent of female students disagree or strongly disagree as opposed to 20 percent of their male counterpart. The second question was "I feel more comfortable posting my opinions on the discussion board rather than to speak up in class". About half of the female students' responses agree or strongly agree and the other half either disagrees or strongly disagrees. On the other hand 63 percent of male students indicated that they preferred to post their opinion on BB and only 35 percent disagreed. The third question was about the students' dependence on their instructors. Almost one third of the female students either agreed or strongly agreed (39 percent) that using online resources made them less dependent on their teachers versus about two third (61 percent) who seem to be dependent on their teachers for help in their learning. Half of the male students agree or disagree ( 50 percent) versus half disagreeing ( 48 percent) that they were less dependent on their teachers for help in their learning. The last question was about whether students have become more confident expressing their ideas using the LMS communication tools, such as email, chat, and discussion forum. The majorities of females' students (89 percent) either agrees or strongly agree with this question. While, only 78 percent of male students agree or strongly agree that using LMS communication tools made more confident. About the same number of female ( 7 percent) and male (10 percent) students seem to disagree or strongly disagree with this question. 


\section{Summary and Conclusions}

A study was conducted to learn about female versus male students' attitude towards using a Learning Management system (Blackboard learn ${ }^{+}$) and their awareness of where and how learning outcomes are used. The survey included three categories: Learning Outcomes, Effective Use of Technology, and Preferred Mode of Communication and Confidence Building. Survey results showed that the majority of male and female students are aware that the University is an outcome based institution and that the College uses specific learning outcomes in all its courses. Students also specified that they knew which learning outcomes are included in their specific course syllabi. Students indicated that online resources were highly available to them on campus and remotely. Furthermore, students agreed to access and use these resources on a daily basis. In the assessment component of the survey, results showed that a fairly high percentage of students preferred taking online exams and assessments and that they regularly check their grades online to follow up with their academic progress. The study showed that the students' preferred mode of communication is email instead of face to face. Particularly, the female's response was stronger than the male's response. This may be due to the fact in this region females prefer not to interact directly with male faculty. Furthermore, using the LMS discussion board was the least preferred mode of communication. A possible reason could be the wide availability of alternative modes of communication such as smart phones. In fact during the last few years, the majority of the students own smart devices such as Blackberry, I phone, as well as other well known brands.

In conclusion, most students felt they became more confident in expressing their opinions and ideas using communication technologies. Students also responded that using online learning has improved their technical skills. Furthermore, while the available web resources allowed them to become independent learners they still needed the guidance of instructors. The knowledge gained from this research could contribute to understanding the online modality of education in this region and help instructors select the most appropriate technological methods to improve learning in a segregated educational environment.

\section{References}

Al-Doub, E., Goodwin, R., \& Al-Hunaiyyan, A. (2008). Student's attitudes toward e-learning in Kuwait's higher education institutions. $16^{\text {th }}$ International Conference on Computers in Education. Taipei, Taiwan. Retrieved from http://www.apsce.net/icce2008 .

Altenhofen, M., \& Schaper, J. (2002). Flexible instructional strategies for e-learning. Proceedings of the 35th Annual Hawaii International Conference on System Sciences (HICSS'02).

Biju, S. M. (2010). E-learning and blended learning in the Gulf. Netherlands: Springer.

Gagne, R. M., Wager, W. W, Golas, K. C., Keller, J. M., \& Russell, J. D. (2005). Principles of instructional design (5th ed.). Wiley.

Hodges, C. (2004). Designing to motivate: Motivational techniques to incorporate in e-learning experience. The Journal of Interactive Online Learning, 2(3).

Kinshuk \& Young, A. (2003). Web-based asynchronous synchronous environment for online learning. Journal of the USDLA, April.

Lee, C. Y. (2000). Student motivation in the online environment. Journal of Educational Media and Library Sciences, 37(4), 367-375.

Maslow, A.H. (1970). Motivation and personality (2nd ed.). New York: Harper and Row.

Muhlhauser, M., \& Trompler, C.(2002). Learning in the digital age: Paving a smooth path with digital lecture halls. Proceedings of HiCSS 35th Hawaii Intl. Conference, Waikola, HI, Jan. 7-12, 2001. pp. 352361, IEEE CS press, Los Alamitos, CA. 
Neubauer, M., \& Lobel, M. (2003). The learning by doing eClassroom. Journal of the USDLA, 17(2), 5-17.

Norman, V. (2007). Perspectives on blended learning in higher education. Journal of ELearning, January.

Smith, M., \& Winking-Diaz, A. (2004). Increasing students' interactivity in an online course. The Journal of Interactive Online Learning, 2(3).

Vekroost, M., Meijerink, L., Linsten, H., \& Veen, W. (2008). Finding a balance in dimensions of blended learning. International Journal on ELearning, 7(3), 499-522.

\section{Appendix A Student Survey Form}

We would like to hear your opinion about using Blackboard in an outcome-based learning environment. The survey will explore the impact and effectiveness of technology on students learning. Please note that the survey will be completely anonymous. Thank you.

GENDER: MALE $\quad$ FEMALE

(1: Strongly Agree, 2: Agree, 3: Disagree, 4: Strongly Disagree)

\begin{tabular}{|l|l||}
\hline Learning Outcomes & Answer \\
\hline I am aware that ZU is an outcome based university. & \\
\hline I know what are the Zayed University Learning Outcomes (ZULO). & \\
\hline I am aware that all IT courses include learning outcomes. & \\
\hline I am aware that learning outcomes are included in the course syllabus. & \\
\hline I know which learning outcomes are included in my IT courses. & \\
\hline $\begin{array}{l}\text { My preferred mode of communication is (circle one): } \\
\text { 1. Email } \\
\text { 3. Phone }\end{array}$ & \\
\hline Technology to Face & \\
\hline I have no problem to accessing Blackboard from home. & \\
\hline I check Blackboard at least once a day. & \\
\hline Communication & \\
\hline I use email to communicate with fellow students. & \\
\hline I use email to communicate with my instructor in this class. & \\
\hline
\end{tabular}




\begin{tabular}{|l|l||}
\hline I have developed the ability to communicate clearly. & \multicolumn{2}{|l|}{} \\
\hline Technical Skill Development & \\
\hline Using online learning has improved my technical skills. & \\
\hline $\begin{array}{l}\text { The web resources listed on the course's webpage allow me to learn more about my } \\
\text { courses. }\end{array}$ & \\
\hline Confidence Development & \\
\hline Using online learning allow me to be more independent. & \\
\hline $\begin{array}{l}\text { I feel more comfortable in posting my opinions on discussion board rather than to speak } \\
\text { up in class. }\end{array}$ & \multicolumn{2}{|l||}{} \\
\hline Using Online Learning make me less dependent on my teachers for help. & \\
\hline I become more confident in expressing my ideas using communication technologies such \\
as email, chat, and discussion forum.
\end{tabular}


Appendix B

Male Female Combined Responses

\begin{tabular}{|c|c|c|c|c|}
\hline & Male Agree & Male Disagree & Female Agree & $\begin{array}{l}\text { Female Dis- } \\
\text { agree }\end{array}$ \\
\hline \multicolumn{5}{|c|}{ Learning Outcomes } \\
\hline Q1 & 97.5 & 0.0 & 73.7 & 22.8 \\
\hline Q2 & 67.5 & 30.0 & 70.9 & 29.0 \\
\hline Q3 & 92.5 & 6.5 & 80.7 & 19.3 \\
\hline Q4 & 90.0 & 7.5 & 77.2 & 22.8 \\
\hline Q5 & 65.0 & 20.0 & 63.2 & 28.1 \\
\hline \multicolumn{5}{|c|}{ Technology use to facilitate learning } \\
\hline Q1 & 72.5 & 25.0 & 91.2 & 8.8 \\
\hline Q2 & 82.5 & 15.0 & 70.2 & 29.8 \\
\hline Q3 & 80.0 & 7.5 & 84.2 & 12.3 \\
\hline Q4 & 80.0 & 5.0 & 87.7 & 5.3 \\
\hline Q5 & 67.5 & 20.0 & 77.2 & 19.3 \\
\hline \multicolumn{5}{|c|}{ Use of technology for communication } \\
\hline Q1 & 67.5 & 30.0 & 70.2 & 29.8 \\
\hline Q2 & 80.0 & 15.0 & 91.2 & 8.8 \\
\hline Q3 & 85.0 & 12.5 & 93.0 & 5.3 \\
\hline \multicolumn{5}{|c|}{$\begin{array}{l}\text { Technical skill develop- } \\
\text { ment }\end{array}$} \\
\hline Q1 & 82.5 & 17.5 & 82.5 & 17.5 \\
\hline Q2 & 92.5 & 5.0 & 75.4 & 24.6 \\
\hline \multicolumn{5}{|c|}{ Confidence development } \\
\hline Q1 & 80.0 & 20.0 & 87.7 & 10.5 \\
\hline Q2 & 62.5 & 35.0 & 50.9 & 49.1 \\
\hline Q3 & 50.0 & 47.5 & 38.6 & 61.4 \\
\hline Q4 & 77.5 & 10.0 & 89.5 & 7.0 \\
\hline \multicolumn{5}{|c|}{$\begin{array}{l}\text { Preferred mode of communication for Fe- } \\
\text { male }\end{array}$} \\
\hline Email & 42.0 & Face to Face & 40.0 & \\
\hline Phone & 14.0 & \multicolumn{2}{|c|}{ Blackboard discussion board } & 5 \\
\hline \multicolumn{5}{|c|}{ Preferred mode of communication for Male } \\
\hline Email & 33.0 & Face to Face & 43.0 & \\
\hline Phone & 5.0 & \multicolumn{2}{|c|}{ Blackboard discussion board } & 3 \\
\hline
\end{tabular}




\section{Biographies}

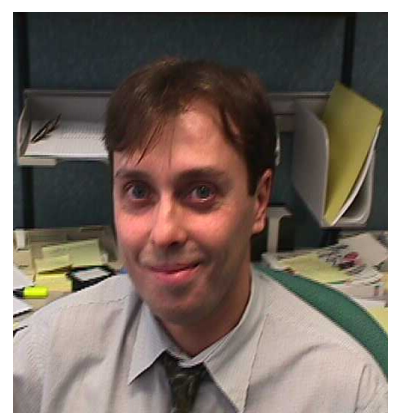

Azzedine Lansari received a $\mathrm{PhD}$ in Bioengineering from North Carolina State University in 1992. From 1992-1998, he was a senior researcher at Computer Sciences Corp. and MANTECH, Inc. He joined Zayed University in August 1998. Currently he is an Associate Professor of Information Technology. His teaching interests include: Computing foundations, web development, systems analysis and design and statistical modeling. His research interests include systems modeling, educational technology and curriculum design.

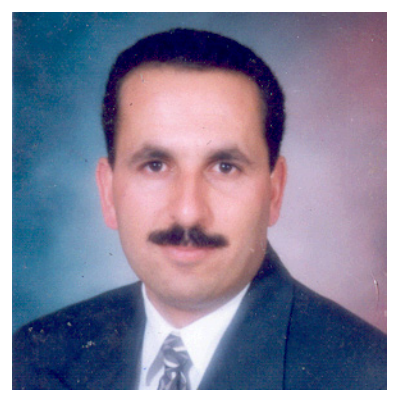

Abdallah Tubaishat is an Associate Professor in the College of Information Technology at Zayed University, United Arab Emirates. He received his $\mathrm{PhD}$ in Software Engineering from Illinois Institute of Technology, IL, USA in 1994. Dr. Tubaishat has fourteen years of experience in teaching and research. His teaching experience include: Software Engineering, Database and Programming, His research interests include e-learning and software engineering. He has published a book with others entitled "Computer Skills", and has around twenty three Journal and conference publications.

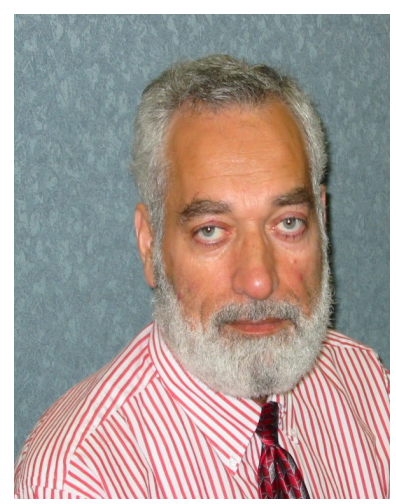

Akram Al-Rawi is currently with DeVry University Online. He has worked at several academic institutions of which the last four were McKendree University, Zayed University, Columbia College, and University of Missouri-Columbia. His teaching interests include programming languages, Digital logic design, Networks and computer architecture. His research interests include computer simulations and curriculum design. He holds certifications in A+, Network+, Security + , I-Net+, Server+, CCNA and CCAI. 